\title{
Deconstructing Identity Struggles of Cross-Cultural People in When We Were Orphans
}

\author{
Wang Fangyuan, Sun Yu, and Zhang Tong
}

\begin{abstract}
When We Were Orphans tells the stories of several cross-cultural people. They have to live in a different country and cultural background because of the Second World War. Being unaccepted by both cultural circles, they constantly lose their original identities. Based on deconstruction theory, this paper reveals confusion of cross-cultural people and evil of war from their deconstructing identity struggles.
\end{abstract}

Index Terms-Cross-culture, deconstruction, identity struggle, When We Were Orphans.

\section{INTRODUCTION}

Kazuo Ishiguro, Japanese-born British novelist and one of the immigrant writers, won the Nobel Prize in Literature in 2017. He owns the dual cultural identities of both Japan and England [1]. When We Were Orphans is his novel published in 2000. It tells the story of a famous detective, Banks. His parents were missing in the old Shanghai city when he was a little boy. Several years later, Banks comes back to Shanghai. $\mathrm{He}$ is so naive that he believes he comes back to save the turbulent world affairs. Finally, he finds that his father elopes with his lover and his mother marries a warlord and suffers all kinds of humiliations to save him. He eventually realizes how weak his power is.

The paper tries to answer two questions. First, do cross-cultural people face identity struggles during the war? Second, if they do, how do they suffer from identity struggle?

\section{LITERATURE PREVIEW}

Since Kazuo Ishiguro won the Nobel Prize in Literature in 2017, his literature works become so popular. Many scholars study his works. However, they usually focus on the study of traumatic Narration, feminism, like Kazuo Ishiguro's Writing of Historical Trauma published in Journal of SCUN, An Analysis of When We Were Orphans from the Perspective of Feminism published in Overseas English and so on. This paper tries to analyze the cross-cultural characters from the perspective of deconstruction.

\section{THEORETICAL FRAMEWORK}

The paper employs deconstruction theory. "Deconstruction

Manuscript received July 24, 2018; revised September 17, 2018. This work was supported by the Seed Foundation of Innovation and Creation for Graduate Students in Northwestern Polytechnical University under Grant ZZ2018244.

The authors are with Northwestern Polytechnical University, Xi'an, China (e-mail: 13201760150@163.com, sunyu@nwpu.edu.cn). is a critique of the relationship between text and meaning originated by the philosopher Jacques Derrida. The purpose of deconstruction is to expose that the object of language, and that which any text is founded upon, is irreducibly complex, unstable, or impossible" [2].

\section{METHODS}

Based on deconstruction theory, this paper employs literature analytical method and takes case study.

\section{ANALYSIS}

\section{A. Banks}

Looking back to the beginning of 20th century in When We Were Orphans, the author finds several cross-cultural characters who fail to get their identities.

The leading character of the novel, Banks lives in Shanghai Concession when he is a little boy. In Shanghai, he cannot fit in the groups of other students in school, which leads to his unsociable personality. The monologue at the beginning part of the novel tells us, "After years of being surrounded by fellows, both at school and at Cambridge, I took great pleasure in my own company" [3].

But he may not realize that he is totally a weird person in the eyes of his schoolmates. In When We Were Orphans, Banks meets his former schoolmates twice. Once, James Osbourne visits him in London, Banks says, "at that point I had yet to receive a single visitor in my rooms" [3]. James recalls the past, shaking his head, and says: "My goodness, you were such an odd bird at school" [3]. Banks clearly disagrees on his comment. "I was not referring to his raising the matter of my 'interrogating' him all those years before. Rather, what I had taken exception to was his casual judgement that I had been such an odd bird at school" [3].

The second meeting happens several days after Banks goes back to Shanghai. His former schoolmate in St Dunstan School Morgan wants to meet him. When they are chatting, Banks glances at him and notices the tears welling in his eyes. Then he says, "You know, we should have teamed up. The two miserable loners. That was the thing to do. You and me, we should have teamed up together. Don't know why we didn't. We wouldn't have felt so left out of things if we'd done that" [3]. Banks is so surprised at his words. He always sees Morgan as a "miserable loner" [3]. Therefore, in Banks' mind, they are definitely different people. He even says to Morgan, "I was always one for mucking in" [3].

Besides, Banks mentions that when he is in Shanghai, "He usually plays with two English brothers living nearby. 
However, sometimes they would be joined by their school friends from Shanghai Public School, then their attitudes towards him would change. He would sometimes become the target of certain pranks" [3]. Obviously, it is hard for Banks to fit in the society of Shanghai.

The important evidence for his identity crisis is that he is unable to fit in the society both in Shanghai and his own country. After Banks comes back to England, he fails to act like a native English man and be well accepted by the English society.

When Banks comes to St Dunstan's, he tries his best to imitate how other native students act. He rapidly absorbs the gestures, phrases, the deeper morals and etiquettes prevailing in his new surroundings. He thinks he did nothing absurd even on his very first day.

However, Banks's careful imitation is not accepted by his schoolmates. For instance, on his fourteenth birthday, Banks receives a gift which is wrapped in numerous sheets from his two schoolmates. When he tries to open the package, his two schoolmates keep laughing at him. Finally, Banks finds his gift is an old magnifying glass. His two schoolmates want to use this magnifying glass to make fun of his dream of being a detective.

Besides, one of his classmates points at him and remarks, "But surely he's rather too short to be a Sherlock" [3]. Other students also laugh at his dream. It seems that Banks is always seen as an absurd person in school.

Although Banks doesn't feel he is weird among his schoolmates in Shanghai, he definitely feels confused about his complicated identity. As a little boy, Banks lives in a society which is quite different from the one in his motherland, which makes his identity obscure. He fails to fit in both the English society and the Chinese one. Once, Little Banks asks Uncle Philip that "I was just wondering. How do you suppose one might become more English?" [3] His question indicates that he is eager to be accepted by the society. He wants an explicit identity.

The identity crisis of Banks is also indicated in his performance in clubs he attends. At the first time he attends the club, Banks couldn't fit in the group. Banks recalls, "I remember standing about frozen with awkwardness, repeatedly sipping from my glass" [3]. He tries to get familiar with other guests. "but my voice sounded conspicuously child-like and most conversations centred on people or issues about which I knew nothing" [3].

The situation doesn't get better when Banks becomes a famous detective. After becoming famous and successful, Banks still cannot adapt to the club. He has to keep reminding himself "not to leave, even if it meant putting up with the odd period of standing about alone" [3]. He doesn't enjoy the club at all. The only reason for attending the clubs is to be "more English" [3].

When Banks' parents are missing, he has to come back to England with the colonel. The colonel notices he is unhappy for leaving Shanghai and reminds him that "you're going to England. You're going home" [3]. Banks deeply resents the colonel's words. For him, he is bound for a strange land. His hometown doesn't give him warmth and intimacy.

In the end of the story, Banks knows that he has no chance to change the tense situation. Even his comfortable life comes from his mother's sacrifice. He has no power to save his parents and the world. He realizes how weak his power is. Therefore, his identity is totally overturned at that time.

Banks has a strong sense of mission. Both Banks and people around him believe he may change the worldwide turbulent situation. He sees his mother as the hero of anti-opium movement. Therefore, he thinks the missing of his parents would have a close connection with the tension. If he can find his parents, he may save the world. The ending is heart-broken. Banks fails to be accepted by both China and Britain. Besides, he has no power to save the world, even himself and his families.

\section{B. Akira}

Akira is Banks's only friend in Shanghai. They share the similar complicated identities. Akira is Japanese who lives in Shanghai. Unlike Banks's family, Akira's parents pay much attention to cultivate Akira's Japanese culture and a sense of belonging.

There is a description of Akira's house in Shanghai. What is most remarkable is the pair of "replica" Japanese rooms. The inner side of the house is totally in Japanese style. Besides, Akira's parents insist on traditional Japanese education. They will be disappointed and angry if Akira is "not enough Japanese" [3].

Before going back to Japan, Akira adores his own country very much. He constantly boasts how great Japan is under his parents' education. Akira boasts so frequently that Banks describes that "my friend would bring to a stop some game we were playing just to lecture me on the latest Japanese building being erected in the business district, or the imminent arrival of another Japanese gunboat in the harbour" [3].

Although Akira lives in Shanghai, he definitely grows up in a typical Japanese family. It seems that Akira can adapt to Japanese life easily. However, "all had not gone well for him in Japan" [3]. Once when they meet outside after Akira comes back from Japan, Akira carelessly made a tear on the sleeve of the kimono. Their reunion is not a big deal but it makes Akira sink into a deep gloom. Then Banks knows the reason why he is so scared is that he has an agreement with his parents that his parents will send him back to Japan if he makes three mistakes. He "mercilessly ostracised for his "foreignness" [3]. Akira is rejected because of his different manners, attitudes, speech and so on. He cannot put up with the unhappy life in Japan. Therefore, his parents bring him back to Shanghai.

Although Akira receives Japanese education from his parents, he fails to find his Japanese identity when he comes back to his country. He is accustomed to the life in Shanghai rather than in Japan.

In the end of the novel, Japanese soldiers mistake Akira for giving information to their enemies and so punish him. Akira is not accepted by his country even to the end of the story. He has the same identity crisis as Banks.

Akira is the most typical character who faces identity struggle. He adores the culture of his own country and is eager to be accepted by Japanese society. He joins the army and wants to make a contribution to his country. Nevertheless, his growing-up experience in Shanghai makes him a foreigner in Japan. Being punished by the Japanese army is also an irony for his identity. As a cross-cultural character, he bears identity 
struggle and fails to get his identity.

\section{Hemmings}

Sarah Hemmings is another typical character who suffers from identity crisis in When We Were Orphans [4]. She tries to join in all the clubs which is full of celebrities. Hemmings clearly knows every noble and famous man. The reason why she is so eager to join in the clubs is that she wants to get close to those celebrities. Actually, according to Banks's description, Hemmings doesn't belong to this celebrity circle. But she joins in the clubs so frequent that most people know her. The common impression she leaves on people is snobbish Hemmings ever engages with the conductor fellow Herriot Lewis. But she leaves him without hesitation after Lewis once made the performance a complete travesty. As Osbourne describes, "Ms. Hemmings dropped him like a hot potato. Threw the engagement ring back at him" [3].

Before Banks becomes a famous detective, he ever tries to chat up Ms. Hemmings. But Hemmings is unwilling to reply him. After Banks becomes well-known, Hemmings finds Banks and asks him to bring her to the club. Banks refuses her request. To our surprise, she doesn't get angry at all and explains to Banks that she does so for her great dream. She wants to find a man to help her change the worldwide tension.

She finally marries with Sir Cecil, obviously a celebrity. They go to Shanghai for saving the serious world's affairs. However, everything is different from what Hemmings predicts. Sir Cecil indulges in gambling after arriving at Shanghai and treats Hemmings very badly. He always insults her. Hemmings still pretends that she lives a good life at first. Finally, she confesses that Sir Cecil is hopeless and realizes that she cannot change the world.

Hemmings is not accepted by the British society because British celebrities see her as a snobbish and unmerciful person. She ever tries her best to save the world. She sees herself as a hero. However, she always wants to find someone to help her achieve the mission instead of relying on herself. In the end, she loses her original dream and presupposed identity. With the identity crisis, Hemmings decides to get rid of her current life to pursue a new and common life.

\section{Banks's Mother}

Banks's mother also faces identity crisis. She is such a person full of sense of justice at the beginning of the story. She is the representative of righteous western people and devotes herself to anti-opium movement [5].

When the inspectors tell Mrs. Banks that they should kick off servants from Shantung because they doubt people from Shantung may have problems in not only hygiene and health, but also honesty. Banks's mother refutes their advice angrily. She insists that opium companies should be responsible for the situation.

Besides, she holds luncheons every week to advertise anti-opium movement. She invites several ladies to attend the luncheons and motivates them to contribute to the movement and fight for justice. She does all she can to fight against opium. As Banks' father works for an opium trade company, the couple usually quarrels for this issue, which is the key reason for the leaving of Banks's father.

Banks' mother devotes herself to anti-opium movement. In
Banks' eyes, she made such a big contribution that she must be very famous. "I held the belief that my mother was known and admired far and wide as the principal enemy of the Great Opium Dragon of China" [3]. However, Banks cannot find any news about her mother. It indicates that her hard-working is not rewarded and her identity also faces crisis.

In the end of the story, the truth is also shocking. The disappearance of Banks' mother is not because of anti-opium movement. She bends to a warlord and suffers all kinds of humiliations in order to provide a rich and comfortable life for Banks. She doesn't concern herself about her anti-opium career anymore. At that time, she only lives for Banks. When Uncle Philip visits her in warlord' house and tells her the situation of anti-opium movement, she doesn't listen and keeps asking about the situation of her son. She entirely loses her identity.

\section{RESEARCH FINDINGS}

Almost everyone in the novel When We Were Orphans loses their identities. It should be attributed to the certain time. The story happens in the Second World War which is an epic warfare. All the characters are obliged to live in another country because of the war. The estrangement from their original countries is so obviously demonstrated in the novel.

Children like Banks and Akira are banned to enter the quarters where Chinese live. They are not accepted by schoolmates in China. The divergence between countries is huge. When Japanese soldiers send Banks back to the embassy, the colonel says the entire world would sink into the war. It is the trend of development.

\section{CONCLUSION}

In that turbulent and complicated time, everyone is constantly losing his or her identity and looks for the truth of life. Cross-cultural people face broken dreams and identity crisis. They are accepted by neither their own country nor other countries. They are constantly looking for their identities in the whole story.

\section{ACKNOWLEDGMENT}

I sincerely hope I can express my thanks to all the people who help me during this research. Firstly, I want to express my sincerely gratitude to my supervisor, Professor Sun Yu. It is impossible for me to do researches without her help. Secondly, I would like to appreciate the support for my research from Seed Foundation of Innovation and Creation for Graduate Students in Northwestern Polytechnical University. Lastly, I'd like to thank the authors in references. They provide me research with inspiration and relevant knowledge.

\section{REFERENCES}

[1] M. Li, "Kazuo Ishiguro's writing of historical trauma," Journal of SCUN, vol. 106, no. 4. pp. 197-202, 2016.

[2] C. Dely and J. Derrida, "The perchance of a coming of the other woman," in The Deconstruction of Phallogocentrism from Duel to Duo, Sens Public, 2007. 
[3] K. Ishiguro, When We Were Orphans, 1st ed. Great Britain, 2000, pp.2-109.

[4] Y. Chen, "An analysis of When We Were Orphans from the perspective of feminism," Overseas English, v01. 561, p. 74.

[5] W. Wang, "The politics of home in Kazuo Ishiguro's When We Were Orphans," Foreign Literature Studies, vol. 39, no. 5, pp. 35-43, 2017.

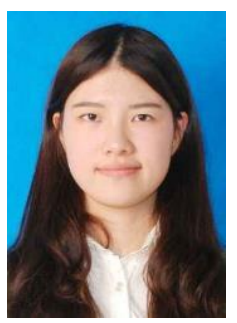

Wang Fangyuan was born in Hefei city, Anhui province in China on March 1st, 1995. She has got the bachelor's degree in Northwestern Polytechnical University, Xi'an city, China in June, 2017 with majored in English. She is pursuing for master's degree in Northwestern Polytechnical University since September, 2017, major in English literature now. Her major study field includes space narration, children literature, and immigrant literature.

She was a teaching assistant in the Middle School Attached to Northwestern Polytechniacal University during March and April in 2017; TOEFL teaching assistant in New Oriental during July and August in 2017; Internship in the People's Government of Shaanxi Province in winter vacation in 2018 .

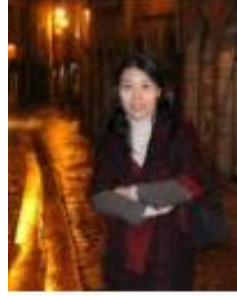

Sun Yu was born in Wuhan, Hubei Province, China She got the bachelor's degree in Xi'an International Studies University in Xi'an, Shaanxi province in 1993, and got the master's degree in Northwestern Polytechnical University in Xi'an, Shaanxi province in 2000. Her major research field includes American literature, western culture, and translation.

She is a professor in School of Foreign Studies in Northwestern Polytechnical University. She is also the head of the Center for Arts Education in NPU.

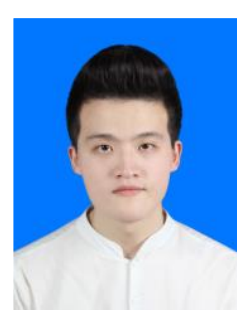

Zhang Tong was born on June 18th, 1995, Fuzhou city, Fujian province, China.

He has got his bachelor of arts in Northwestern Polytechnical University, Xi'an, China, in June, 2017. And he is pursuing the master's degree, majoring in applied linguistics in Northwestern Polytechnical University since September, 2017. His major Field of study is dialects.

He was a teaching assistant in the Middle School Attached to Northwestern Polytechnical University during March and April in 2017, and an assistant of Foreign Affairs Office of People's Government of Shaanxi Province. His current research interests include dialects. 